\title{
PRAKTIK PEMBAGIAN HARTA WARIS DI KAMPUNG ADAT PEDUKUHAN JALAWASTU KABUPATEN BREBES
}

\author{
Muhamad Dzakkii \\ Universitas Islam Sultan Agung Semarang \\ Email: muhamaddzakkii84@gmail.com \\ Mohammad Noviani Ardi \\ Universitas Islam Sultan Agung Semarang \\ Email:mn.ardi@unissula.ac.id \\ DOI: 10.37876/adhki.v2i1.28
}

\begin{abstract}
This article aims to describe the implementation of the distribution of inheritance in the Jalawastu Hamlet community and analyze the implementation of the distribution of inheritance in terms of Islamic law. The method used in analyzing the problem is descriptive-qualitative, which describes the phenomenon of the implementation of the distribution of inheritance in the Jalawastu Hamlet community by directly interviewing the Jalawastu Hamlet community. The next stage is to analyze the practice of the distribution of inheritance in terms of Islamic law. The results of the study stated that the practice of distributing inheritance to the people of Jalawastu Hamlet still uses the custom of distributing inheritance only to children, no portion is given to other heirs. In its distribution, the Jalawastu Hamlet community gave more shares to the children who took care of the heir before he died. This kind of division is not in accordance with the division that has been arranged in the Qur'an systematically. But still the law is valid because in each division has been through the willingness of the family so it does not cause a dispute.
\end{abstract}

Keywords: The practice of distributing inheritance, customary villages, Jalawastu

\begin{abstract}
Abstrak
Artikel ini bertujuan untuk mendeskripsikan pelaksanaan pembagian harta warisan dalam masyarakat Dusun Jalawastu dan menganalisis pelaksanaan pembagian harta warisan ditinjau dari hukum Islam. Metode yang digunakan dalam menganalisis permasalahan tersebut adalah deskriptif-kualitatif, yaitu mendeskripsikan fenomena pelaksanaan pembagian harta warisan dalam masyarakat Dusun Jalawastu dengan langsung mewawancarai masyarakat Dusun Jalawastu. Tahap berikutnya yaitu menganalisis praktik pembagian harta warisan ditinjau dari hukum Islam. Hasil penelitian menyatakan praktik pembagian harta warisan pada masyarakat Dusun Jalawastu masih menggunakan adat kebiasaan yaitu membagikan harta warisan hanya kepada anak, tidak ada bagian yang diberikan kepada ahli waris lain. Dalam pembagiannya, masyarakat Dusun Jalawastu memberikan bagian lebih terhadap anak yang mengurusi pewaris sebelum ia meninggal dunia. Pembagian semacam ini tidak sesuai dengan pembagian yang telah diatur di dalam al-Qur'an secara sistematis. Akan tetapi tetap hukumnya sah karena dalam setiap pembagian sudah melalui kerelaan dari pihak keluarga sehingga tidak menimbulkan pertikaian.
\end{abstract}

Kata Kunci: Praktik pembagian harta waris, kampung adat, Jalawastu

\section{Pendahuluan}

Agama Islam adalah agama yang diturunkan oleh Allah kepada manusia melalui Rasul-Nya, yang berisi hukum yang mengatur hubungan manusia dengan Allah, hubungan manusia dengan manusia dan hubungan manusia dengan alam semesta. Didalamnya juga terdapat aturan dan hukum yang dapat digunakan sebagai 
pedoman dan pegangan hidup bagi seluruh umat agar selamat, baik di dunia dan akhirat. ${ }^{1}$

Hukum waris merupakan salah satu syariat yang diatur di dalam ajaran agama Islam, yakni suatu hukum yang mengatur harta peninggalan seseorang yang telah meninggal dunia, diberikan kepada seseorang yang berhak menerimanya seperti keluarga dan masyarakat yang lebih berhak. ${ }^{2}$

Hukum kewarisan adalah hukum yang mengatur tentang pemindahan hak pemilikan harta peninggalan (tirkah) pewaris, menentukan siapa-siapa yang berhak menjadi ahli waris dan berapa bagiannya masing-masing. ${ }^{3}$

Di Indonesia ada berbagai macam adat dan budaya, serta latar belakang yang melandasi kehidupan masyarakatnya. Begitupula dalam hukum waris adat sangatlah beragam, tergantung pada sifat kedaerahan dari adat tersebut. Banyaknya jumlah suku bangsa yang ada di Indonesia brarti banyak pula jumlah hukum waris adat yang ada. Pada zaman sekarang ini masih ada juga masyarakat adat yang dapat bertahan dan mempertahankan nilai-nilai kearifan lokalnya meskipun arus globalisasi mengalir secara deras. ${ }^{4}$

Dari uraian di atas, maka penulis tertarik untuk meneliti lebih mendalam tentang masyarakat adat Jalawastu. Jalawastu merupakan suatu dukuh yang berada di Ciseureuh Ketanggungan Brebes. Pada tahun 2015 Jalawastu ditetapkan sebagai kampung cagar budaya sesuai dengan peraturan daerah nomor 1 tahun 2015. ${ }^{5}$ Dengan penetapan peraturan tersebut, eksistensi masyarakat beserta kearifan lokalnya mulai diakui dan mulai diperhatikan oleh pemerintah daerah.

Pada masyarakat adat Jalawastu ini hampir sama permasalahan yang dihadapi oleh masyarakat adat lainnya yang berbeda di Indonesia, yaitu kelestarian budayanya di zaman modern semakin terancam dan tergerus, dengan beberapa nilai-nilai kearifan lokalnya yang mulai ditinggalkan. Masyarakat adat ini berada di wilayah Jawa Tengah tepatnya di Kabupaten Brebes, Kecamatan Ketanggungan, Desa Ciseureuh, Dusun Jalawastu. Sesuai dengan lokasi keberadaannya, masyarakat adat itu disebut dengan masyarakat adat Jalawastu.

Penelitian ini berusaha mengungkap lebih jauh tentang tinjauan hukum Islam terhadap praktik pembagian harta waris di adat tersebut, karena lokasinya yang berada di pedalaman hutan dan akses jalan yang belum memadai sehingga keberadaannya tidak banyak diketahui masyarakat luas.

\section{Metode penelitian}

Jenis penlitian ini adalah penelitian kualitatif. Teknik pengumpulan data yang digunakan dalam penelitian ini adalah observasi, wawancara dan dokumentasi. Data

\footnotetext{
1 H. T. Amir Husain Sardany, Pendidikan Agama Islam untuk Perguruan Tinggi, (Surabaya: Grasindo,1987) h.18

${ }^{2}$ Achmad Yani, S.T., M.Kom, Faraidh E Mawari, (Jakarta: KENCANA, 2016, Cet.1) h.3

${ }^{3}$ Departement Agama, Kompilasi Hukum Islam (Bandung: CV.Nuansa Aulia, Cet 5, 2013) h.51

${ }_{4}$ Muhammad Taufiq, et all, "Pasuwitan: Sebagai Legalitas Perkawinan: Telaah Hukum Islam terhadap Perkawinan Suku Samin di Kabupaten Pati", dalam Ulul Albab: Jurnal Studi dan Penelitian Hukum Islam, Vol. 1, No. 2, (Jurusan Syariah Universitas Islam Sultan Agung Semarang, 2018), 56. DOI: http://dx.doi.org/10.30659/jua.v1i2.2768

${ }^{5}$ Perda Brebes, No.1, 2015
} 
yang diperoleh tersebut baik secara lisan dan tulisan di analisis oleh peneliti dan akan dijadikan kesimpulan. Peneliti melakukan observasi di dukuh Ciseureuh selama 3 hari dengan malihat langsung aktivitas masyarakat sekitar di Pedukuhan Jalawastu Desa Ciseureuh. ${ }^{6}$

Selama observasi, peneliti juga mewawancarai beberapa tokok termasuk ketua adat dalam menggali keterangan lebih jelas tentang adat pembagian waris di di Pedukuhan Jalawastu Desa Ciseureuh. ${ }^{7}$ Adapun narasumber dalam penelitian ini adalah para masyarakat Pedukuhan Jalawastu Desa Ciseureuh Ketanggungan Brebes. Untuk mengetahui bagaimana praktek pembagian waris dikalangan masyarakat Jalawastu.

\section{Praktik Pembagian Harta Waris di Dusun Jalawastu}

Dalam praktek pembagian harta warisan keluarga di Dusun Jalawastu, Desa Ciseureuh, kecamatan Ketanggungan, Kabupaten Brebes masih menggunakan hukum waris adat. Hukum waris adat ialah himpunan kaidah sosial dalam masyarakat luas, tidak termasuk hukum syara' (agama). ${ }^{8}$ Mengenai pembagian harta warisan di Dusun Jalawastu, Desa Ciseureuh, Kecamatan Ketanggungan, Kabupaten Brebes masih menggunakan peraturan adat yang berasal dari orang tua terdahulu yang secara turun temurun dipakai di Dusun Jalawastu, atau bisa dibilang warisan nenek moyang mereka yang diwariskan secara turun menurun oleh anak, cucu dan seterusnya. ${ }^{9}$

Berdasarkan hasil studi lapangan dari beberapa narasumber menunjukkan bahwa masyarakat Dusun Jalawastu masih memegang erat peraturan yang dipegang dari orang tua terdahulu yang mana praktik pembagian harta warisan masih menggunakan peraturan adat.

Selain dari pada itu penentuan bagian untuk ahli waris dalam pembagian harta warisan di Dusun Jalawastu, Desa Ciseureuh, Kecamatan Ketanggunagan, Kabupaten Brebes menurut adat Jalawastu, masih menggunakan hukum adat, yaitu mesamaratakan seluruh bagian yang diterima ahli waris, tidak memandang apakah itu laki-laki atau perempuan, semua dianggap sama. Akan tetapi ada bagian khusus yang diberikan dari pewaris kepada anak yang terakhir kali mengurusi pewaris sebelum ia meninggal dunia. Barang siapa ada anak yang mengurusi pewaris sebelum ia meninggal dunia maka ia berhak mendapatkan bagian dari harta warisan. ${ }^{10}$

Ahli waris yang mendapatkan harta warisan dari pewaris hanyalah anak, tidak ada bagian yang didapatkan keluarga pewaris selain anak. Ayah, ibu, saudara dan keluarga lainnya tidak mendapatkan harta warisan. Dalam hal pembagiannya, masyarakat Dusun Jalawastu tidak mengutamakan anak perempuan ataupun anak laki-laki. Semua mendapat bagian harta warisan yang sama kecuali seseorang yang

${ }^{6}$ Didiek Ahmad Supadie, Bimbingan Penulisan Ilmiah Buku Pintar Menulis Skripsi, (Semarang: Unissula Press, Cetakan Kedua, 2017) h.107

7 Jogiyanto Hartono M, Metoda Pengumpulan dan Teknik Analisis Data, (Yogyakarta: CV.Andi Offset,2018) h.61

${ }^{8}$ M.Abdul Mujieb, dkk. Kamus Istilah Figh. h.3

9 Wawancara dengan DRS, tanggal 4 Februari 2020 di rumah kediaman DRS; SDR, tanggal 4 Februari 2020 di rumah kediaman DRS

${ }^{10}$ Wawancara dengan DRSN, tanggal 5 Februari 2020 di rumah kediaman DRSN 
terakhir mengurus pewaris sebelum ia meninggal dunia, maka ia berhak mendapatkan bagian lebih. Hal ini tidak menjadi pertikaian diantara keluarga, karena setiap hasil pembagian yang dilakukan sudah melalui permufakatan, dan masyarakat Dusun Jalawastu selalu menerima apa yang telah menjadi bagiannya. Karena masyarakat di Dusun Jalawastu sangat menghormati peraturan adat atau peraturan yang diturunkan turun temurun dari orang tua terdahulu.

Adapun mengenai waktu kapan dibagikannya harta warisan setelah pewaris meninggal dunia terdapat waktu tertentu. Pembagian harta warisan akan dilakukan setelah semua urusan yang berhubungan dengan si mayyit sudah terpenuhi, baru setelah itu harta warisan bisa dibagikan termasuk didalamnya hitungan keperluan untuk 7 hari kematian, 40 hari, dan 100 hari. ${ }^{11}$

Hal ini menandakan bahwa masyarakat Dusun Jalawastu sangat memperdulikan dan menghormati si mayyit. Harta warisan bukanlah tujuan atau pokok pembahasan yang utama bagi setiap ahli waris, akan tetapi rasa kemanusiaan lah yang menjadi pegangan pokok masyarakat Dusun Jalawastu.

Dari paparan diatas diketahui bahwa ketika seseorang meninggal dunia, harta yang dimiliki si mayyit tidak langsung dibagikan, melainkan digunakan untuk kepentingan pengurusan jenazah terlebih dahulu baru setelah itu harta pewaris bisa dibagikan.

Apabila seorang pewaris tidak mempunyai anak, baik kandung maupun angkat, maka harta warisan dibagikan kepada keluarga yang mengurusi atau merawat pewaris sebelum dia meninggal dunia. Ketikapun pewaris tidak mempunyai keluarga maka harta waris diserahkan kepada pemangku adat untuk di alokasikan untuk kemaslahatan bersama.

\section{Tinjuan Hukum Islam Terhadap Praktik Pembagian Harta Waris di Dusun Jalawastu}

Masyarakat Dusun Jalawastu Desa Ciseureuh Kecamatan Ketanggungan Kabupaten Brebes, 100\% menganut agama Islam. Sehingga seluruh aspek kehidupan dan perilakunya banyak dilakukan dengan penuh kebiasaan. Sistem pembagian harta warisan menurut hukum Islam tidak tampak dibandingkan sistem waris adat karena pembagian harta warisan telah menjadi budaya pada masyarakat Dusun Jalawastu. Hal tersebut disebabkan sebelum agama Islam menjadi pegangan yang kuat di Dusun Jalawastu, masyarakat di Dusun Jalawastu telah memiliki pedoman hidup yang dipegang erat yang diwariskan turun temurun dari orang tua terdahulu.

Pemahaman masyarakat Dusun Jalawastu Desa Ciseureuh Kecamatan Ketanggungan Kabupaten Brebes terhadap pembagian harta warisan mengikuti peraturan adat, sebagaimana ungkapan Bapak DRSN selaku pemangku adat Dusun Jalawastu yang mengatakan bahwa pembagian waris dilakukan secara kekeluargaan dan mengikuti peraturan yang berlaku dimasyarakat Jalawastu yaitu menyama ratakan semua bagian waris, tanpa memandang laki-laki dan perempuan, dan memberi bagian khusus kepada ahli waris yang terakhir kali mengurusi pewaris. ${ }^{12}$

${ }_{11}$ Wawancara dengan DRSN, tanggal 5 Februari 2020; ZA, tanggal 5 Februari 2020 di rumah kediaman ZA

12 Wawancara dengan DRSN, tanggal 5 Februari 2020 di rumah kediaman DRSN 
Berdasarkan kebiasaan masyarakat Dusun Jalawastu, ahli waris yang menerima harta warisan ialah anak. Tidak ada bagian lain selain bagian itu jatuh kepada anak. Alasan mengapa hanya anak yang mendapatkan harta warisan karena seorang anak lah yang nanti akan melanjutkan tradisi-tradisi yang ditinggalkan dari orang tuanya, dan anak lah yang paling layak mendapatkan warisan karena hubungannya yang paling dekat dengan orang tua. Dibalik itu semua, seorang anak lah yang nantinya akan bertanggung jawab terhadap orang tua, baik ibu atau bapak, kakek atau nenek, jadi harta warisan yang diberikan kepada anak semata-mata bukan untuk foya-foya dan bersenang-senang, melainkan mempunyai tanggungan untuk menanggung beban orang tua yang masih hidup. Terkecuali untuk sebuah keluarga yang tidak mempunyai anak, maka harta warisan diserahkan kepada kerabat lainnya, seperti kakek, nenek, saudara laki-laki.

Harta waris dibagikan rata kepada anak dari pewaris, baik anak itu laki-laki atau perempuan. Mungkin kita sering menemui pembagian harta waris semacam ini dikalangan masyarakat lainnya, akan tetapi ada hal unik yang ditemukan pada masyarakat Dusun Jalawastu ini. Yaitu penambahan harta yang diberikan kepada anak yang mengurusi orang tuanya sebelum ia meninggal. Anak tersebut diberikan bagian lebih karena jasanya yang telah mengurus pewaris sebelum ia meninggal. Masyarakat Jalawastu sangat mengapresiasi perbuatan baik dari seorang anak karena mau mengurusi apapun kebutuhan yang dibutuhkan pewaris, karena meluangkan waktu untuk mengurusi pewaris merupakan suatu hal yang tidak bisa dianggap mudah. Dengan kesibukan yang ada, ia rela menyisikan waktu untuk merawat orang tua, walaupun mengurus dan mewarat kedua orang tua adalah kewajiban setiap anak, akan tetapi tidak semua anak bisa dan mampu melakukannya dengan kesibukankesibukan yang sedang ia jalankan. Maka adat atau tradisi masyarakat Dusun Jalawastu memberikan bagian lebih terhadap anak yang mau mengurusi orang tua sebelum ia meninggal dunia.

Dalam hal ini, Allah telah menentukan ahli waris dan bagian-bagiannya secara terstruktur. Dijelaskan dalam Al-Qur'an surat an-Nisa ayat 7, 11, 12, dan 176.

Dalam QS an-Nisa ayat 7 Allah Swt. Berfirman :

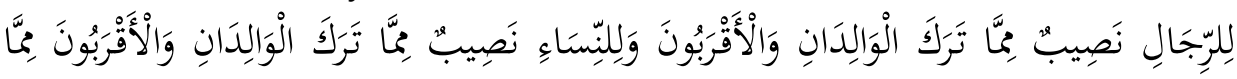

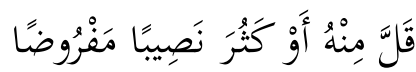

"Bagi orang laki-laki ada hak bagian dari harta peninggalan ibu-bapak dan kerabatnya, dan bagi orang wanita ada hak bagian (pula) dari harta peninggalan ibu-bapak dan kerabatnya, baik sedikit atau banyak menurut bahagian yang telah ditetapkan."

Pada ayat tersebut dijelaskan untuk menyamakan kedudukan antara laki-laki dan perempuan dalam hal mendapatkan harta warisan. Islam mengatur sistem kewarisan dengan sangat sempurna, tidak ada diskriminasi terhadap laki-laki maupun perempuan. Masyarakat di Dusun Jalawastu Desa Ciseureuh Kecamatan Ketanggungan Brebes dalam memberikan harta warisan sudah sejalan dengan aturan Islam, laki-laki dan perempuan mendapatkan harta warisan dari pewaris. 
Mengenai besaran bagian yang didapatkan ahli waris, Allah Swt sudah mengatur dengan jelas bagian-bagian ahli waris dalam QS an-Nisa ayat 11-12 yang telah dijelaskan pada bab sebelumnya.

Ayat tersebut menjelaskan dalam penerimaan hak waris antara anak laki-laki dan anak perempuan, hak suami dan istri, serta hak ayah dan ibu terdapat kesamaan hak. Apabila terdapat anak laki-laki dan perempuan secara bersamaan maka anak lakilaki mendapatkan bagian dua kali lipat dari bagian anak perempuan. Ayah dari pewaris mendapatkan 1/6 apabila bersama anak laki-laki atau cucu laki-laki, dan mendapatkan bagian ashobah atau sisa apabila ada anak perempuan atau cucu perempuan. Begitupun Ibu, Ibu dari pewaris mendapatkan bagian 1/3 apabila tidak ada anak dari pewaris dan mendapatkan bagian 1/6 apabila bersama anak dari pewaris. Dan untuk bagian kakek, nenek, cucu, saudara dan seterusnya akan termahjub atau terhalangi apabila masih ada anak, ayah dan ibu.

Dalam penentuan siapa saja yang akan menerima harta warisan, masyarakat Dusun Jalawastu belum memakai pedoman yang sudah diatur secara sistematis didalam Al-Qur'an. Harta warisan dari pewaris hanya dibagikan kepada anakanaknya. Ayah, ibu, saudara dan seterusnya tidak mendapatkan harta warisan walaupun mereka masih hidup dan ada bersama keluarga pewaris.

Hal ini bertentangan dengan kaidah waris Islam. Allah Swt menurunkan ayat yang menjelaskan tentang waris agar umat manusia menaati itu. Allah Swt tidak semata-mata menurunkan ayat yang menerangkan tentang waris secara percuma, ada hikmah dibalik itu semua. Hikmah yang bisa diambil dari pembagian harta waris ialah:

1. Memuliakan kepemilikan individu, yang mana Islam telah memutuskan untuk menjadikan harta pustaka / harta yang diwariskan (tirkah) mayit sebagai milik ahli warisnya dengan tepat satu per satu.

2. Harta warisan diberikan kepada orang yang paling dekat hubungan kekeluargaannya dengan mayit karena ia (mayit) telah terbantu oleh mereka selama hidupnya dan kebanyakan mereka juga memiliki peran besar dibalik pembentukan kekayaannya.

3. Telah ditentukan bagi setiap ahli waris bagian yang jelas, yang dengannya hilang bebagai sumber perpecahan yang menanamkan kedengkian dan terputusnya hubungan keluarga.

4. Ditetapkannya bagian perempuan separuh bagian laki-laki (kebanyakan) karna laki-laki telah menanggung keluarga, ia juga menanggung beban infak dan mahar, adapun perempuan tidak ada tanggungan memberi nafkah, justru ialah yang ditanggung oleh ayahnya dan suaminya.

5. Dimasukkannya pasangan (suami / istri) sebagai kerabat dalam rangka menghormati hubungan pernikahan dan menampakkan pemandangan sebagai pemenuhan janji.

6. Dimasukkannya al-wala (orang yang telah memerdekakan hamba sahaya) sebagai kerabat sebagai pengakuan atas perbuatan baiknya dan sebagai rasa terima kasih. ${ }^{13}$

${ }^{13}$ Aisyah As-Salafiyah, Ilmu Faraidh dan Mawaris (Bogor: Pustaka Amma Alamia, 2018) h.4-5 
Masyarakat Dusun Jalawastu sangat mematuhi apa saja ketentuan yang ditinggalkan dari orang tua terdahulu, termasuk masalah kewarisan. Pembagian semacam ini tidak menjadi pertikaian didalam masyarakat Dusun Jalawastu. Masyarakat Dusun Jalawastu menerima berapapun bagian yang ia dapatkan, mereka percaya bahwa harta yang ditinggalkan pewaris tidak bisa menjadikannya kaya. Masyarakat Dusun Jalawastu sudah terbiasa hidup sederhana walaupun ia mempunyai ladang pertanian yang luas dan peternakan yang banyak. Mereka percaya semua itu merupakan titipan Allah dan akan kembali kepada Allah. Kekayaan harta bukan suatu hal yang utama yang harus dicapai, akan tetapi kerukunan manusialah yang sangat mereka harapkan.

Melihat kasus tersebut diatas tentunya perlu diketahui penyelesaian atau jalan keluar berdasarkan ketentuan yang ada didalam Al-Qur'an dan tidak boleh menyimpang dari Al-Qur'an. Dengan jalan al-shulhu atau perdamaian diantara ahli waris setelah ahli waris tersebut mengetahui bagiannya masing-masing. ${ }^{14}$

Wahbah al-Zuhaili mengemukakan bahwa al-shulhu berasal dari bahasa arab yang berarti putus pertengkaran. Sedangkan dalam pengertian syara' shulhu adalah suatu perjanjian yang dibuat untuk menyelesaikan perselisihan. ${ }^{15}$ Dengan demikian, suatu putusan berdasarkan atas kesadaran bersama dari pihak yang berperkara, sehingga tidak ada menang atau kalah merupakan definisi perdamaian. ${ }^{16}$

Dalam Kompilasi Hukum Islam (KHI) telah diatur tentang al-shulhu atau perdamaian dalam membagi harta warisan, hal tersebut terdapat dalam pasal 183 yang menjelaskan bahwa: "para ahli waris dapat bersepakat melakukan perdamaian dalam pembagian harta warisan setelah masing-masing menyadari bagiannya."17

Berdasarkan keterangan diatas maka pembagian harta waris hukumnya sah apabila setiap ahli waris yang menerima bagiannya secara rela membaginya dengan cara perdamaian atau kekeluargaan dengan kesepakatan setiap anggota keluarga. Bahkan berdasarkan hal tersebut, pembagian harta waris sah bilamana ada di antara ahli waris yang menggugurkan atau merelakan haknya dalam pembagian harta warisan itu untuk diberikan kepada ahli waris yang telah ditentukan bagiannya dengan adat kebiasaan masyarakat Dusun Jalawastu.

\section{Kesimpulan}

Berdasarkan hasil penelitian yang dilakukan, peneliti dapat disimpulkan sebagai berikut bahwa praktek pembagian harta waris yang dilakukan oleh masyarakat Dusun Jalawastu Desa Ciseureuh Kecamatan Ketanggungan Brebes menggunakan peraturan adat atau kebiasaan, yaitu membagi harta waris hanya kepada anak dan menyamaratakn bagian tersebut. Ditinjau dari Hukum Islam dalam hal Ilmu Waris, praktek pembagian harta waris yang dilakukan masyarakat Dusun Jalawastu Desa Ciseureuh Kecamatan Ketanggungan Brebes tidak sesuai dengan

14 YouTube, 2018, Juli 24, Hukum Waris Dibagi Rata - Buya Yahya (berkas video). Diperoleh dari https://youtu.be/MZ8eGHjOwlA

${ }^{15}$ Wahbah al-Zuhaili, figh al-islam wa adillatu, juz VI, damaskus: daar al-fikr, 2004.

${ }^{16}$ M Yahya Harahap, Kedudukan Kewenangan dan Acara Peradilan Agama, (Jakarta: Pustaka Kartini, Cet III, 1993) h.47

${ }^{17}$ Departement Agama, Kompilasi Hukum Islam, h. 55 
hukum waris Islam. Kebiasaan masyarakat Dusun Jalawastu membagikan harta waris hanya kepada anak merupakan suatu bentuk ketidak adilan. Adapun seharusnya harta waris dibagikan secara menyeluruh sesuai bagian yang telah ditentukan dalam Q.S. An-Nisa ayat 7,11,12,176. Akan tetapi pembagian harta waris sah apabila setiap ahli waris secara rela membagi bagiannya dengan cara kekeluargaan atau perdamaian sesuai dengan kesepakatan setiap pihak keluarga. Dalam KHI pasl 183 telah diatur tentang pembagian harta waris, bahwa setiap para ahli waris dapat bersepakat melakukan perdamaian harta waris setelah masing-masing menyadari bagiannya.

\section{Daftar pustaka}

Aisyah, Ilmu Faraidh dan Mawaris (Bogor: Pustaka Amma Alamia, 2018)

Al-Zuhaili, Wahbah, figh al-islam wa adillatu, juz VI, damaskus: daar al-fikr, 2004.

Amir Husain, S, Pendidikan Agama Islam untuk Perguruan Tinggi, (Surabaya: Grasindo,1987)

Arikunto, Suharsini, Prosedur Penelitian (Jakarta: PT Rineka Cipta, 2013)

A, Z, Jalawastu, (2019 Februari Selasa). Tinjauan Hukum Islam Terhadap Praktek Pembagian Harta Waris di Pedukuhan Jalawastu Desa Ciseureuh Kecamatan Ketanggungan Brebes. (M.Dzaki, Interviewer)

DRS, Jalawastu, (2019 Februari Selasa). Tinjauan Hukum Islam Terhadap Praktek Pembagian Harta Waris di Pedukuhan Jalawastu Desa Ciseureuh Kecamatan Ketanggungan Brebes. (M.Dzaki, Interviewer)

DRSN, Jalawastu, (2019 Februari Selasa). Tinjauan Hukum Islam Terhadap Praktek Pembagian Harta Waris di Pedukuhan Jalawastu Desa Ciseureuh Kecamatan Ketanggungan Brebes. (M.Dzaki, Interviewer)

Departement Agama, Kompilasi Hukum Islam (Bandung: CV.Nuansa Aulia, Cet 5, 2013)

Didiek Ahmad, S, Bimbingan Penulisan Ilmiah Buku Pintar Menulis Skripsi, (Semarang: Unissula Press, Cet 2, 2017)

Gugun, Dastam, Jalawastu, (2019 Februari Selasa). Tinjauan Hukum Islam Terhadap Praktek Pembagian Harta Waris di Pedukuhan Jalawastu Desa Ciseureuh Kecamatan Ketanggungan Brebes. (M.Dzaki, Interviewer)

Harahap, M Yahya, Kedudukan Kewenangan dan Acara Peradilan Agama, (Jakarta: Pustaka Kartini, Cet III, 1993)

Jogiyanto Hartono, M, Metoda Pengumpulan dan Teknik Analisis Data, (Yogyakarta: CV.Andi Offset, 2018)

Mujieb, M Abdul, dkk. Kamus Istilah Figh.

Perda Brebes, No.1, 2015

SDR, Jalawastu, (2019 Februari Selasa). Tinjauan Hukum Islam Terhadap Praktek Pembagian Harta Waris di Pedukuhan Jalawastu Desa Ciseureuh Kecamatan Ketanggungan Brebes. (M.Dzaki, Interviewer)

Taufik, Muhammad, et all. Pasuwitan: Sebagai Legalitas Perkawinan: Telaah Hukum Islam terhadap Perkawinan Suku Samin di Kabupaten Pati. dalam Ulul Albab: Jurnal Studi dan Penelitian Hukum Islam, Vol. 1, No. 2, (Jurusan Syariah Universitas Islam Sultan Agung Semarang, 2018. DOI: http://dx.doi.org/10.30659/jua.v1i2.2768

Yani, Achmad, Faraidh \& Mawari, (Jakarta: KENCANA, Cet.1, 2016) 